\title{
EFFECT OF HEAT TREATMENT AND PLASMA NITRIDING ON CORROSION RESISTANCE OF 440B MARTENSITIC STAINLESS STEEL
}

\author{
Magdalena ŁĘPICKA*, Małgorzata GRĄDZKA-DAHLKE*
}

${ }^{*}$ Faculty of Mechanical Engineering, Department of Materials and Biomedical Engineering, Bialystok University of Technology, ul. Wiejska 45 C, 15-351 Bialystok, Poland

\author{
m.lepicka@doktoranci.pb.edu.pl, m.dahlke@pb.edu.pl
}

\begin{abstract}
Reliability and durability assurance poses a serious challenge for surgical instruments manufacturers. Hard working conditions, such as intermittent contact with body fluids and hard bone tissues, as well as necessity to undergo frequent sterilisation processes, induce constant research into solutions capable of ensuring high wear resistance while maintaining satisfactory imperviousness to corrosion. Plasma nitriding is marked as the modern corrosion resistance improving method suitable for surgical instruments steels. The paper presents findings from the heat treated and plasma nitrided AISI 440B (PN EN or DIN X90CrMoV18) steel corrosion resistance studies. Three conventionally heat treated (quenched with tempering in 250,390 or $605^{\circ} \mathrm{C}$ ) and three additionally plasma nitrided in $\mathrm{N}_{2}: \mathrm{H}_{2}$ reaction gas mixture (50:50, 35:65 and 20:80 ratio, respectively) specimens groups were examined. Furthermore, the authors evaluated the effect of machining - polishing and sandblasting - on investigated steel corrosion resistance. Microscopic observations and electrochemical corrosion tests were performed using a variety of analytical techniques. Results showed that, in comparison to conventional heat treatment, plasma nitriding of 440B stainless steel does not significantly affect its corrosive characteristics as far as the uniform nitride layer over the entire detail surface is obtained. The layer heterogeneity results in intensification of corrosion processes, making the material even more susceptible to corrosion than after conventional heat treatment, and contributing to severe, visible even with the unaided eye damages development.
\end{abstract}

Key words: Stainless Steels, Corrosion, Heat Treatment, Plasma Nitriding, Surgical Instruments

\section{INTRODUCTION}

Reliability and durability are the most important factors in surgical instruments manufacturing. Hard working conditions, such as intermittent contact with body fluids and hard bone tissues, necessity to undergo sterilisation processes, impose constant research into solutions able to ensure high wear resistance while maintaining resistance to corrosion (Marciniak, 1992; Paszenda and Tyrlik-Held, 2003). To assure the required durability of surgical instruments, cutting instruments are often made of martensitic stainless steels (PN-EN ISO 7153-1:2002; PN-EN 10088-1:2005; Paszenda and Tyrlik-Held, 2003). Made of these, the instruments are subjected to heat treatment to obtain high hardness and, as a result, sufficient wear resistance (Marciniak, 1992). Moreover, thermo chemical surface modification techniques such as anti-wear layers deposition are commonly applied in the technological process (Głowacka, 1996; Rudnik, 1996). Alas, not all solutions traditionally used in machining are allowed in biomedical applications because of the peril of corrosion characteristics deterioration. Therefore, when searching for ways to improve operative surgical instruments characteristics, resistance to wear and corrosion ought be accounted.

Considering cutting surgical instruments, the commonly used surface modification technique is the plasma nitriding. The method can be briefly described as impingement of a flux of ions to the surface of the treated parts. The treated batch surface is activated by glow discharge which increases the efficiency of the process. Due to the concentration gradient, nitrogen diffuses into the treated workpiece. As a result of chemical reactions, the mechanical properties of the material are modified at both the top and subsurface level (Tuckart et al., 2007).

Conventional plasma nitriding conducted in the temperatures from 500 to $600^{\circ} \mathrm{C}$ significantly improves the microhardness and the tribological properties of stainless steels (Tuckart et al., 2007), but also causes a significant decrease in their corrosion resistance (Li and Bell, 2006; Hi et al., 2008a; Xi et al., 2008b). Corrosion resistance reduction is due to the exudation of $\mathrm{CrN}$ precipitates, which creation results in the chromium content depletion in the nitrided surface matrix (Xi et al., 2008a). This phenomenon can be observed only in certain treatment temperature range, causing the sensitivity of steel to intergranular corrosion. To avoid this negative effect, a thermo chemical heat treatment method called low temperature plasma nitriding (LTN) has been established (Bell and Sun, 2002). The highest corrosion resistance of martensitic stainless steels is usually obtained when tempering below $425^{\circ} \mathrm{C}$ (Grubb, 2011). Typically, the LTN nitriding is carried out at a temperature of about $420^{\circ} \mathrm{C}$, since it allows to obtain phase called nitrogen expanded austenite $-\gamma_{\mathrm{N}}$ (Mingolo et al., 2006; Samandi et al., 1993). Its main features include very high hardness, high wear resistance, and - above all - excellent corrosion resistance (Li and Bell, 2006; Xi et al., 2008a). As opposed to, the martensitic stainless steels heat treatment at the temperatures in the range from 245 to $540^{\circ} \mathrm{C}$ may lead to increased susceptibility to stress corrosion or hydrogen embrittlement (Grubb, 2011). The direct cause of this phenomena are the chromium-rich a' phase precipitates in the ferritic matrix. This 
formation, likewise the occurring at above $20 \%$ chromium content hard and brittle a-phase formation, can be characterised by low transformation kinetics and can often be avoided (Hedström, 2007). The ensuing a' precipitates cause not only grain boundaries chromium content depletion, but also induce considerable internal stresses. Occurence of the tensile stress in the material fosters hydrogen, fatigue and stress corrosion processes existence (Baszkiewicz and Kamiński, 2006). In consequence, the stainless steel is no longer stainless.

The substantiation for tempering temperatures exceeding $245^{\circ} \mathrm{C}$ avoidance of martensitic stainless steels is precipitation of chromium carbide $\mathrm{Cr}_{23} \mathrm{C}_{6}$ (Yang et al., 2007). Typically, it is formed at temperatures from 500 to $800^{\circ} \mathrm{C}$, but if the grain boundaries contain carbides seeds its precipitation can begin even at $300^{\circ} \mathrm{C}$ (Baszkiewicz and Kamiński, 2006). In case of chromium carbide presence, steel becomes susceptible to intergranular corrosion. Chromium diffusion from grain interiors to their boundaries is characterised by much greater dynamics than the carbon diffusion. This directly causes chromium content reduction; in the adjacent to the grain boundary layer total chromium content can reach even nought, on average remains at the level of $2 \%$ (Baszkiewicz and Kamiński, 2006). Chemical segregation leads to formation of anodic areas - the low in chrome boundaries - and cathodic areas - chromium-rich grain interiors. Moreover, the anode to cathode ratio is highly disadvantageous cathodic areas are many times larger than the anodic ones, leading to a dynamic material dissolution at the grain boundaries.

In view of this information, selection of appropriate heat treatment parameters for steels used for surgical instruments appears as an important issue when ensuring optimal performance characteristics.

The aim of this study was to evaluate the corrosion resistance of heat treated at different temperatures and then plasma nitrided martensitic stainless steel.

\section{MATERIALS AND METHODS}

AISI 440B (PN-EN X90CrMoV18) stainless steel was selected as the substrate material. The chemical composition of the tested material is presented in Tab. 1.

Tab. 1. 440B stainless steel chemical compotision (wt $\%)^{21}$

\begin{tabular}{|c|c|c|c|c|c|}
\hline & $C$ & $M n$ & Si & $S$ & $\mathbf{P}$ \\
\hline$E D X$ & 0.95 & - & 0.40 & 0.39 & 0.30 \\
\hline $\begin{array}{c}P N-E N \\
10088 \\
-1: 2005\end{array}$ & $\begin{array}{c}0.85 \\
\div 0.95\end{array}$ & $\begin{array}{l}\max \\
1.00\end{array}$ & $\max 1.00$ & $\max 0.040$ & $\max 0.030$ \\
\hline & $\mathrm{Cr}$ & Mo & $\mathrm{V}$ & $\mathrm{Fe}$ & \\
\hline$E D X$ & 18.00 & 0.95 & 0.06 & remnant & \\
\hline $\begin{array}{c}P N-E N \\
10088 \\
-1: 2005\end{array}$ & $\begin{array}{c}17.00 \\
\div 19.00\end{array}$ & $\begin{array}{c}0.90 \\
\div 1.30\end{array}$ & $\begin{array}{c}0.07 \\
\div 0.12\end{array}$ & remnant & \\
\hline
\end{tabular}

The research material has been prepared accordingly to the technological process applied for surgical drill bits manufacturing. The substrate material was heat treated (series 1-6) and plasma nitrided (series 7-12). The effect of tempering temperature and surface modification on subjected material corrosion resistance has been investigated.
Specimens were subjected to heat treatment, consisting of quenching in oil, from an austenitising temperature of $1030^{\circ} \mathrm{C}$, and tempering. The tempering temperature is extremely important when considering desired properties of the steel. Tempering in low temperatures (up to $250^{\circ} \mathrm{C}$ ) provides the highest hardness. However, the following procedure, plasma nitriding, is performed at higher temperatures. Nevertheless, a fairly wide heat treatment temperature range is not recommended for martensitic stainless steels due to their corrosion resistance, as it was described in the Introduction. Therefore, in this study three tempering temperatures: 250,390 and $605^{\circ} \mathrm{C}$ were considered. Samples were prepared in form of discs with $8 \mathrm{~mm}$ diameter and $6 \mathrm{~mm}$ height. They were subjected to mechanical surface treatment consisting of sandblasting, typical for surgical instruments manufacturing process, or polishing, to assess if lesser surface roughness provides significantly better corrosion resistance.

Specimens from series 7 to 12 were additionally subjected to plasma nitriding carried out at temperature from 380 to $400^{\circ} \mathrm{C}$, under working pressure of $200 \mathrm{~Pa}$. The whole process lasted 2 hours. In order to optimize nitriding process conditions, the process was repeated in three different concentrations of treatment gases inside working chamber, namely:

a) $50 \% \mathrm{H}, 50 \% \mathrm{~N}$, i.e. $100 \mathrm{ml} / \mathrm{min}_{2}+100 \mathrm{ml} / \mathrm{min} \mathrm{N}_{2}$,

b) $35 \% \mathrm{H}, 65 \% \mathrm{~N}$, i.e. $70 \mathrm{ml} / \mathrm{min}_{2}+130 \mathrm{ml} / \mathrm{min} \mathrm{N}_{2}$,

c) $20 \% \mathrm{H}, 80 \% \mathrm{~N}$, i.e. $40 \mathrm{ml} / \mathrm{min}_{2}+160 \mathrm{ml} / \mathrm{min} \mathrm{N}_{2}$.

All analysed samples are summarised in Tab. 2.

Tab. 2. Specimens summary table

\begin{tabular}{|c|c|c|c|c|}
\hline $\begin{array}{c}\text { Series } \\
\text { no. }\end{array}$ & $\begin{array}{c}\text { Quenching } \\
\text { temperature } \\
\left({ }^{\circ} \mathrm{C}\right)\end{array}$ & $\begin{array}{c}\text { Tempering } \\
\text { temperature } \\
\left({ }^{\circ} \mathrm{C}\right)\end{array}$ & $\begin{array}{l}\text { Surface } \\
\text { machining }\end{array}$ & $\begin{array}{c}\text { Plasma } \\
\text { nitriding; } \\
\text { working } \\
\text { gas } \\
\text { compositon }\end{array}$ \\
\hline 1 & \multirow{2}{*}{1030} & \multirow{2}{*}{250} & polishing & - \\
\hline 2 & & & sandblasting & - \\
\hline 3 & \multirow{2}{*}{1030} & \multirow{2}{*}{390} & polishing & - \\
\hline 4 & & & sandblasting & - \\
\hline 5 & \multirow{2}{*}{1030} & \multirow{2}{*}{605} & polishing & - \\
\hline 6 & & & sandblasting & - \\
\hline 7 & \multirow{6}{*}{1030} & \multirow{6}{*}{250} & polishing & \multirow{2}{*}{$\begin{array}{c}50 \% \mathrm{H}_{2} \\
+50 \% \mathrm{~N}_{2}\end{array}$} \\
\hline 8 & & & sandblasting & \\
\hline 9 & & & polishing & \multirow{2}{*}{$\begin{array}{c}35 \% \mathrm{H}_{2} \\
+65 \% \mathrm{~N}_{2}\end{array}$} \\
\hline 10 & & & sandblasting & \\
\hline 11 & & & polishing & \multirow{2}{*}{$\begin{array}{c}20 \% \mathrm{H}_{2} \\
+80 \% \mathrm{~N}_{2}\end{array}$} \\
\hline 12 & & & sandblasting & \\
\hline
\end{tabular}

Polarisation studies were performed electrochemically in $0.9 \mathrm{wt} \% \mathrm{NaCl}$ aqueous solution to investigate the electrochemical corrosion behaviour of the conventionally heat treated and the plasma nitrided specimens. Potentiodynamic polarisation scans were carried out using a computer controlled ATLAS 9833 (AtlasSollich) corrosion system. The $\mathrm{NaCl}$ solution was maintained at $25^{\circ} \mathrm{C}$ open to air. A constant scan rate of $0.001 \mathrm{~V} / \mathrm{s}$ was used. All potentials were measured with respect to a saturated calomel electrode (SCE, $0.242 \mathrm{~V}$ in $25^{\circ} \mathrm{C}$ vs. SHE at $25^{\circ} \mathrm{C}$ ) as the reference electrode. The set consisted also of platinum auxiliary electrode and a working electrode (sample). Theoretic circular area of $50.24 \mathrm{~mm}^{2}$ was left to maintain contact with the testing solution. Tests were performed according to the following procedures: (i) 
clean sample from organic and non-organic debris in ultrasonic cleaner using ethyl alcohol in room temperature $\left(20^{\circ} \mathrm{C}\right)$, (ii) rinse sample with deionised water, (iii) place the sample in a three-neck flask pre-filled with $250 \mathrm{~cm}^{3}$ fresh, un-deaerated $0.9 \% \mathrm{NaCl}$ solution, (iv) stabilise for 120 minutes, (v) perform polarisation scan from $-0.6 \mathrm{~V}$ to a potential of up to $+2 \mathrm{~V}$. Test control, data logging and processing were achieved by a POL99-win computer software.

The morphology and pit structure of specimens were studied by scanning electron microscopy (SEM - Hitachi S-3000N microscope), confocal laser scanning microscopy (CLSMO - Olympus LEXT OLS 4000 microscope) and energy-dispersive X-ray analysis (EDX).

\section{RESULTS AND DISCUSSION}

The applied heat and thermo chemical treatments parameters resulted in a change in the corrosion resistance of tested steel, as shown in Figs. 1-5.

The first group of investigated samples consisted of conventionally heat treated specimens. Figure 1 illustrates the polarisation curves of $440 \mathrm{~B}$ steel tempered in $250^{\circ} \mathrm{C}$. It is noticeable that sandblasted sample is characterised by significantly lower corrosion currents density and corrosion potential shift towards positive potentials, what is typical of better corrosion resistance. In investigated measuring range, no transpassivation has been observed. Curves are mild, free of current jumps.

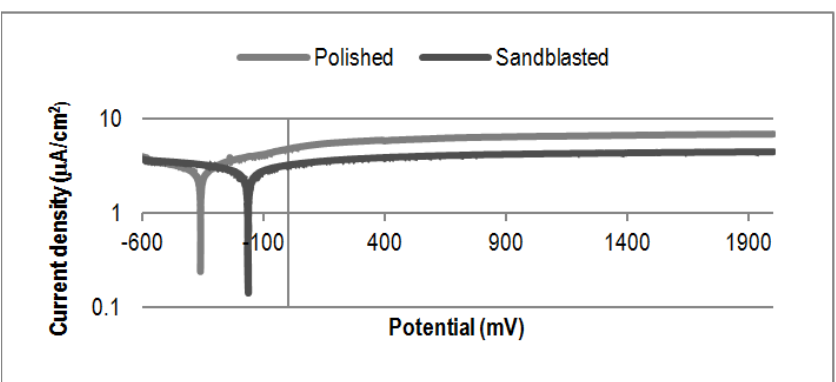

Fig. 1. Polarisation curves of tempered in $250^{\circ} \mathrm{C} 440 \mathrm{~B}$ steel in $0.9 \mathrm{wt} \%$ $\mathrm{NaCl}$ solution (undeaerated, unstirred)

A similar trend can be observed considering steel tempered in $390^{\circ} \mathrm{C}$ (Fig. 2). However, in this case current density jumps can be noticed for both polished and sandblasted specimens. Such behaviour is characteristic for corrosion pits nucleation. What is important, current density jump of sandblasted sample occurs at significantly greater corrosion potential value than of the polished one. This is a factor indicating better corrosion resistance of non-polished material.

It could be expected that surface roughness reduction obtained by polishing would have a positive influence on examined steel corrosion characteristics. However, an inverse relationship can be observed. This fact can be explained by sandblast induced material reinforcement. Workpiece surface sandblasting entails preferred from both corrosion resistance and hardness increase compressive stresses emergence. It can be deduced that sandblasted areas do not conduce to pits nucleation, and even layer of corrosion products seems to confirm this thesis. In contrast, surface grinding and polishing can lead to microscopic local defects development, which act as pits nucleation areas. As a result, sandblasted 440B steel exhibits better corrosion properties than the polished one.

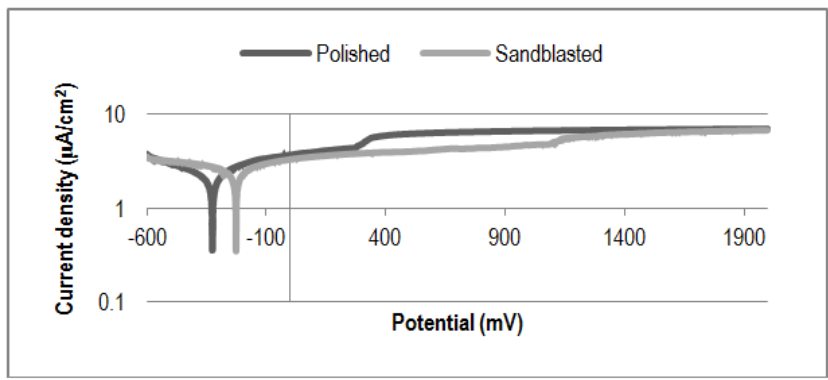

Fig. 2. Polarisation curves of tempered in $390^{\circ} \mathrm{C} 440 \mathrm{~B}$ steel in $0.9 \mathrm{wt} \%$ $\mathrm{NaCl}$ solution (undeaerated, unstirred)

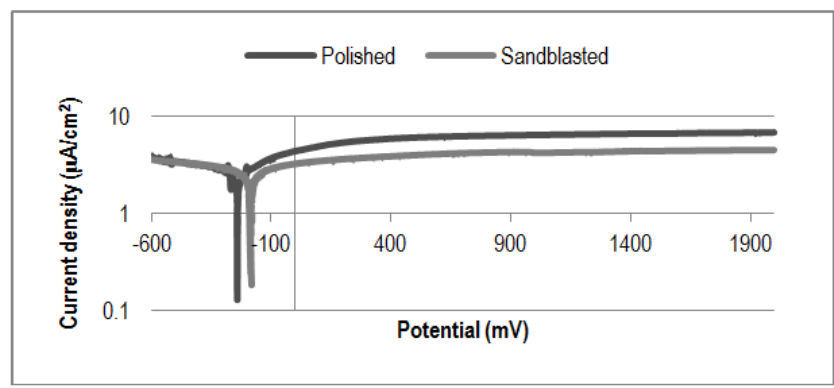

Fig. 3. Polarisation curves of plasma nitrided in $35: 65 \mathrm{H}_{2}: \mathrm{N}_{2}$ gaseous mixture $440 \mathrm{~B}$ steel in $0.9 \mathrm{wt} \% \mathrm{NaCl}$ solution (undeaerated, unstirred)

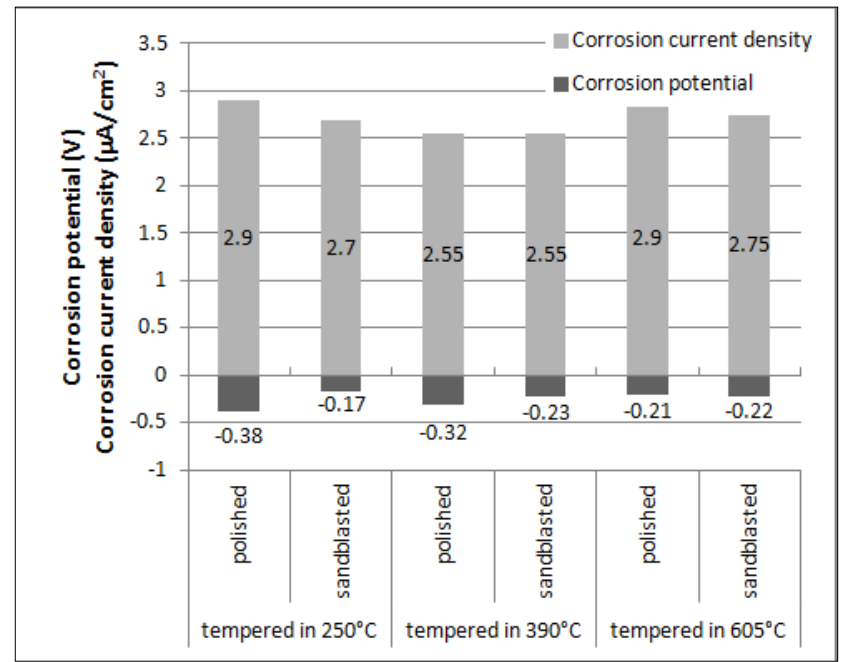

Fig. 4. Conventionally heat treated specimens corrosion potentials and corrosion currents densities

Analysis of nitrided samples polarisation curves also showed that the initial state of material surface has an effect on its corrosion characteristics. In the first two nitriding options - with reactive gas mixture $50: 50$ and $35: 65 \mathrm{H}_{2}$ to $\mathrm{N}_{2}$ ratio - the initial specimens surface topography affected their corrosion resistance after the nitriding process, while the third reaction gas mixture variation (80:20) had virtually no impact on considered properties.

For example, the plasma nitrided in $35: 65 \mathrm{H}_{2}: \mathrm{N}_{2}$ gaseous mixture sandblasted steel exhibited slightly greater corrosion potential and lower corrosion current value (Fig. 3). The curves are mild, after some elapsed experiment time both of them achieve rectilin- 
earity - the polished one approximately at $200 \mathrm{mV}$, and the sandblasted one - after reaching $0 \mathrm{mV}$.

Figs. 4 and 5 present corrosion potentials and corrosion current densities obtained from graphical Tafel approximation. According to the findings, plasma nitriding can be recommended as a corrosion resistance enhancing method only for details that have already been polished. Admittedly, a significant decrease in corrosion currents is not achieved, but the curve shift towards positive potentials is observed. Therefore, the polarisation characteristics can be modified, what leads to passivation time extension. In this case, when applying plasma nitriding regardless of the reactive gaseous mixture composition, an additional approximately $0.2 \mathrm{~V}$ cathodic polarisation potential is provided.

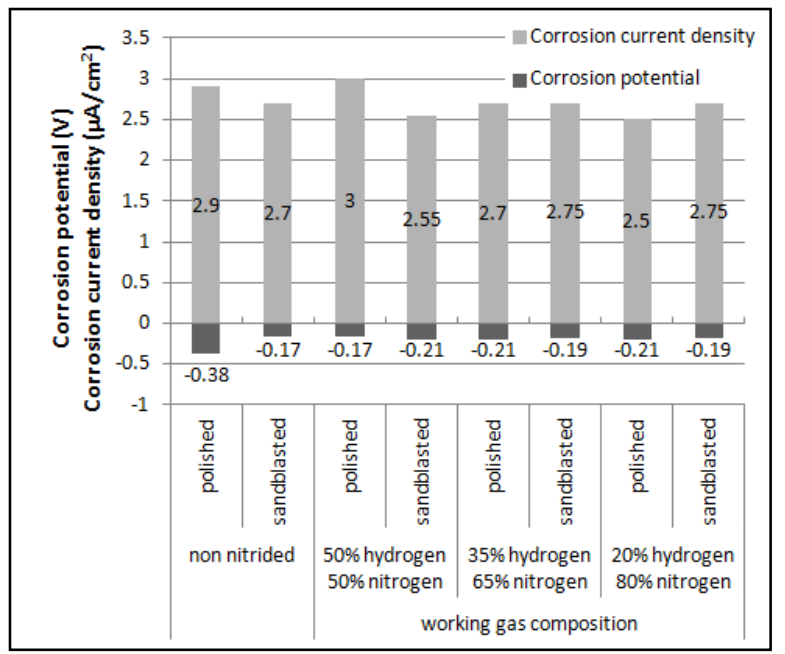

Fig. 5. Tempered in $250^{\circ} \mathrm{C}$ specimens after conventional heat treatment or plasma nitriding - corrosion potentials and corrosion currents densities comparison
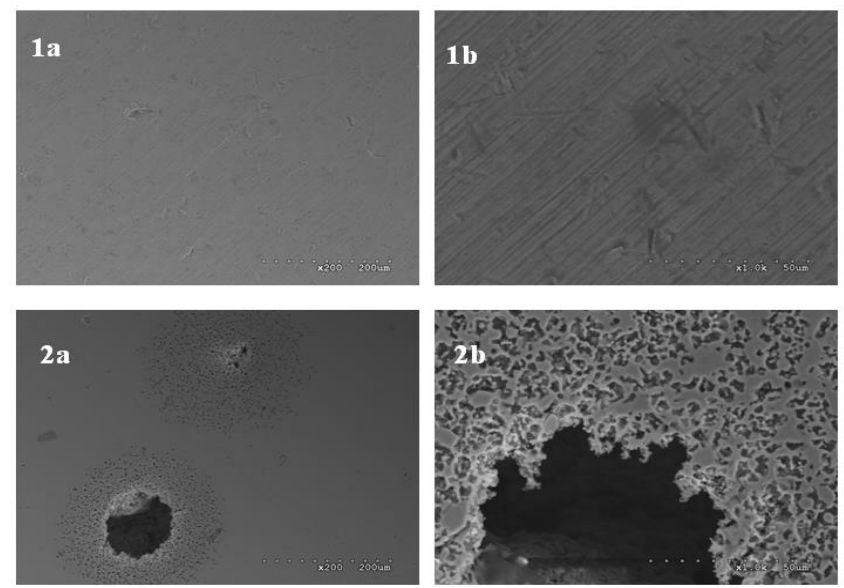

Fig. 6. Corroded surface morphologies of tempered in $250^{\circ} \mathrm{C} 440 \mathrm{~B}$ steel after potentiodynamic polarisation scans; $1 \mathrm{a}, 1 \mathrm{~b}$ - sandblasted steel, $2 \mathrm{a}, 2 \mathrm{~b}$ - polished steel. SEM photographs, 200× (1a, 2a) and $1000 \times(1 b, 2 b)$ magnification

The performed microscopic observations also confirmed greater corrosion resistance of sandblasted specimens. Fig. 6 illustrates tempered in $250^{\circ} \mathrm{C}$ sandblasted and polished specimens surfaces after corrosion analyses. It can be noticed that sandblasted sample surface (Fig. 6, 1b) is free of corrosion pits; at higher magnification only machining traces are visible.
The observed corrosion was of uniform nature; the red-brown colour of saline solution indicates presence of iron (III) oxidehydroxide. The superficial material perforation was present round the vast corrosion damages (Fig. 6, 2a). If the solution is not mixed, formation of fine corrosion pits around the greater damages may be induced by dynamic processes occurring in the directly contacting sample surface aqueous environment.

Different corrosion damages were observed on plasma nitrided specimens. Relatively small samples dimensions (height $=6$ $\mathrm{mm}$, diameter $=8 \mathrm{~mm}$ ) constitute difficulties in obtaining uniform nitrided layers on surrounded by long edges flat surfaces. Irregular reactive mixture propagation makes impossible to obtain planned layer thickness and composition. Specimen rims present distinct surface layer, while the core remains in the same state as before the whole process began or some traces of transitional layer can be observed (Fig. 7). Obtained findings indicate that the nitriding gas concentration has a significant effect on the extent of nitrided layer zone. It can be observed that the greater the hydrogen to nitrogen ratio disproportion is, the less satisfactory surface modification is achieved.

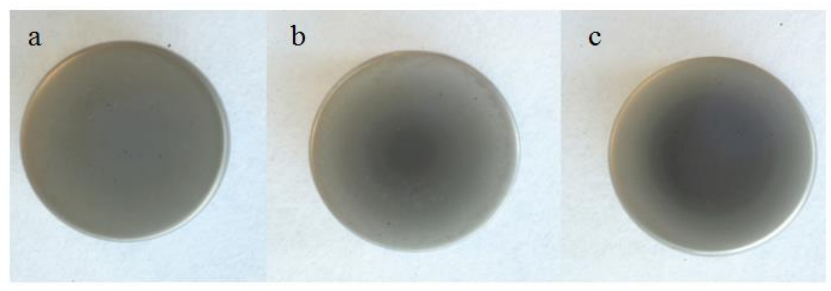

Fig. 7. Plasma nitrided polished specimens; a - $50 \% \mathrm{H}_{2}: 50 \% \mathrm{~N}_{2}, \mathrm{~b}-35 \%$ $\mathrm{H}_{2}: 65 \% \mathrm{~N}_{2}, \mathrm{C}-20 \% \mathrm{H}_{2}: 80 \% \mathrm{~N}_{2}$; macro photographs

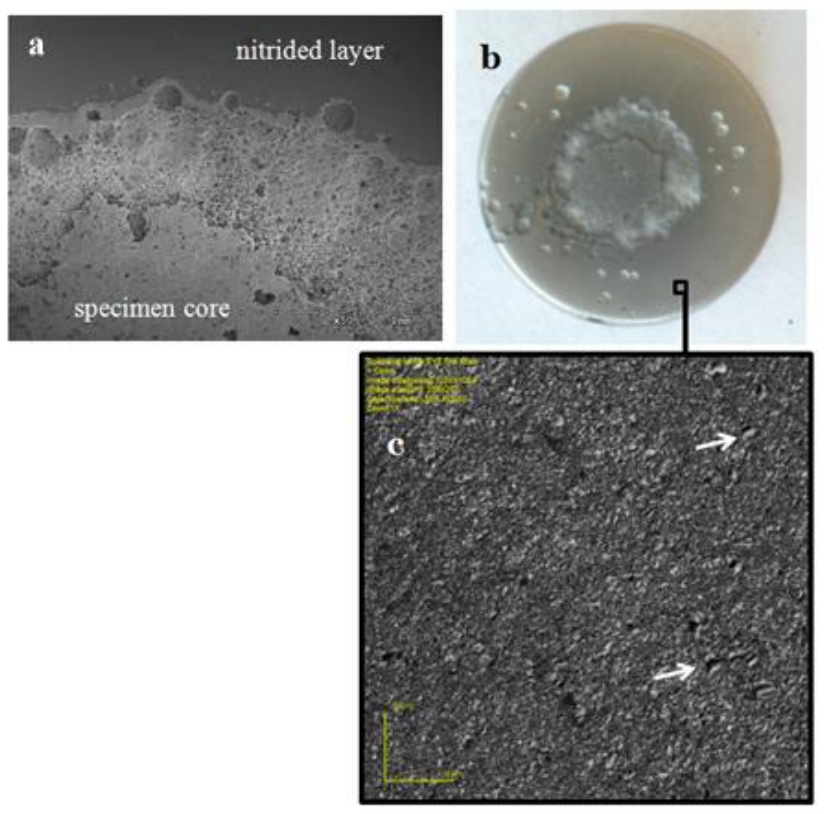

Fig. 8. Corroded surface morphology of plasma nitrided in $35: 65 \mathrm{H}_{2}: \mathrm{N}_{2}$ working gas mixture 440B steel; a - SEM photograph, magnification 50x; b - macro photograph; $c$ - confocal microscope photograph in $1080 \times$ magnification, arrows - transition phase particles

Uneven nitrided layer adversely affects discussed steel corrosion resistance in chemically aggressive environment. The pres- 
ence of varying in chemical composition areas leads to selective dissolution of the material, resulting in extensive damages at the edge-core interface (Fig. 8). The tightly covered with external layer area assumes the role of the cathode, while the specimen core - material that was to be protected - becomes the progressively dissolved anode. What is important, in these circumstances the original surface finish - sandblast or polishing - becomes insignificant when considering its influence on corrosion processes dynamics. Therefore, a predominant influence on corrosion processes has the modified layer extent.

\section{SUMMARY}

The aim of conducted study was to evaluate corrosion resistance of $440 \mathrm{~B}$ type martensitic stainless steel after conventional heat treatment and plasma nitriding. The obtained findings analysis enabled authors to draw following conclusions:

- Material tempered in 250 or $390^{\circ} \mathrm{C}$ is characterised by similar corrosion resistance. High temperature tempering is not recommended due to martensitic steel sensitisation to intergranular corrosion.

- The 440B stainless steel plasma nitriding applied in order to extend the surgical instruments life cycle does not significantly affect its corrosion resistance as far as the uniform nitride layer over the entire detail surface is obtained.

- The nitrided layer heterogeneity results in intensification of corrosion processes, making the material even more susceptible to corrosion than after conventional heat treatment and contributing to severe, visible even with the unaided eye damages development.

\section{REFERENCES}

1. Baszkiewicz J., Kamiński F. (2006), Materials corrosion, Publishing Office of Warsaw University of Technology, Warszawa.

2. Bell T., Sun Y. (2002), Low temperature plasma nitriding and carburising of austenitic stainless steels, Advanced Materials And Processes, Vol. 160, No. 6, 49-51.

3. Głowacka M. (1996), Metallography, Publishers of Gdansk Technical University, Gdansk

4. Gösta W. (1985), Base of corrosion and metals protection, WNT Warszawa.

5. Grubb J. F. (2011), Martensitic stainless steels in Uhlig's Corrosion Handbook (by Revie R. W.) , John Wiley and Sons, Hoboken.

6. Hedström P. (2007), Deformation and Martensitic Phase Transformation in Stainless Steels, Lulea University of Technology, Lulea.

7. Li C. X, Bell T. (2006), Corrosion properties of plasma nitrided AIS 410 martensitic stainless steel in $3.5 \% \mathrm{NaCl}$ and $1 \% \mathrm{HCl}$ aqueous solutions, Corrosion Science, Vol. 48, No. 8, 2035-2049.

8. Marciniak J. (1992), Biomaterials in bone surgery, Publishers of Silesian University of Technology, Gliwice.

9. Mingolo N., Tschiptschin A. P., Pinedo C. E. (2006), On the formation of expanded austenite during plasma nitriding of an AISI $316 \mathrm{~L}$ austenitic stainless steel, Surface and Coatings Technology, Vol. 201, No. 7, 4215-4218.

10. Paszenda Z., Tyrlik-Held, J. (2003), Surgical instrument, Publishers of Silesian University of Technology, Gliwice.

11. Pinedo C. E., Monteiro W. A. (2004), On the kinetics of plasma nitriding a martensitic stainless steel type AISI 420, Surface and Coatings Technology, Vol. 179, No. 2-3, 119-123.

12. Rudnik S. (2006), Metallography, PWN, Warszawa.
13. Samandi M., Shedden B. A., Smith D. I., Collins G. A., Hutchings R., Tendys J. (1993), Microstructure, corrosion and tribological behaviour of plasma immersion ion-implanted austenitic stainless steel,Surface and Coatings Technology, Vol. 59, No. 1-3, 261-266.

14. Tuckart W., Forlerer E., lurman L. (2007), Delayed cracking in plasma nitriding of AISI 420 stainless steel, Surface \& Coatings Technology, Vol. 202, No. 1, 199-202.

15. Wu K., Liu G. Q., Wang L., Xu B. F.(2010) Research on new rapid and deep plasma nitriding techniques of AISI 420 martensitic stainless steel, Vacuum, Vol. 84, No.6, 870-875.

16. Xi Y., Liu D., Han D. (2008a), Improvement of corrosion and wear resistances of AISI 420 martensitic stainless steel using plasma nitriding at low temperature, Surface \& Coatings Technology, Vol. 202, No. 12, 2577-2583.

17. Xi Y., Liu D., Han D. (2008b) Improvement of erosion and erosioncorrosion resistance of AISI420 stainless steel by low temperature plasma nitriding, Applied Surface Science, Vol. 254, No. 18, 59535958

18. Yang S., Wang Z. J., Kokawa H., Yutaka S. S. (2007). Grain boundary engineering of 304 austenitic stainless steel by laser surface melting and annealing, Journal of Materials Science, Vol. 42 , No. 3, 847-853.

19. PN-EN ISO 7153-1:2002 Surgical instruments. Metallic materials Stainless steel.

20. PN-EN ISO 8044:2002 Corrosion of metals and alloys - Basic terms and definitions.

21. PN-EN 10088-1:2005 Stainless steels. List of stainless steels.

Acknowledgement: This scientific work was supported by the Faculty of Mechanical Engineering, Bialystok University of Technology, project No S/WM/1/2009. 